\title{
LA-UR-20-28581
}

Approved for public release; distribution is unlimited.

Title: $\quad$ SEE LANL: Student Educational Experience at LANL

Author(s): $\quad$ Root, Margaret A.

Koehler, Katrina Elizabeth

Intended for: University presentation

Issued: 
Disclaimer:

Los Alamos National Laboratory, an affirmative action/equal opportunity employer, is operated by Triad National Security, LLC for the National Nuclear Security Administration of U.S. Department of Energy under contract 89233218CNA000001. By approving this article, the publisher recognizes that the U.S. Government retains nonexclusive, royalty-free license to publish or reproduce the published form of this contribution, or to allow others to do so, for U.S. Government purposes. Los Alamos National Laboratory requests that the publisher identify this article as work performed under the auspices of the U.S. Department of Energy. Los Alamos National Laboratory strongly supports academic freedom and a researcher's right to publish; as an institution, however, the Laboratory does not endorse the viewpoint of a publication or guarantee its technical correctness. 


\section{SEE LANL}

Student Educational Experience at LANL

Co-PIs: Katrina Koehler and Margaret Root

October 23, 2020

- Los Alamos NATIONAL LABORATORY 


\section{What is the purpose of SEE LANL?}

- To provide university students a hands-on nuclear safeguards training course based on the courses given to all IAEA inspectors

- To encourage networking and collaborations between university students/professors and laboratory staff

- To introduce students to the variety of safeguards-related technical work at LANL

- To provide early-career

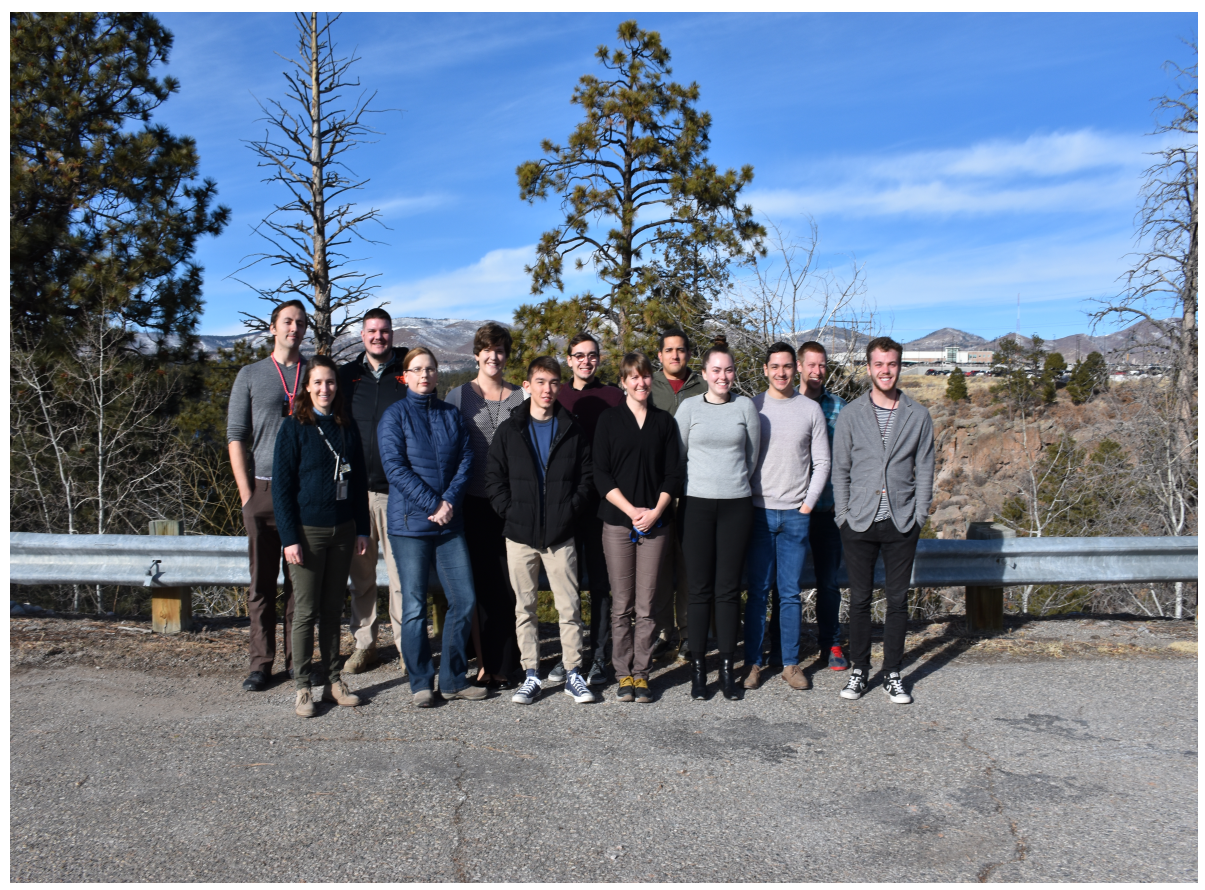
technical staff an opportunity to teach 
Which universities have participated in SEE LANL?

\section{Oregon State University}

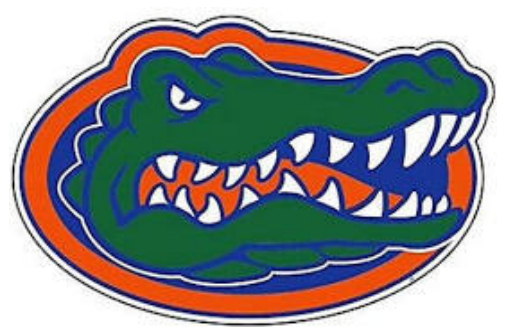

ton

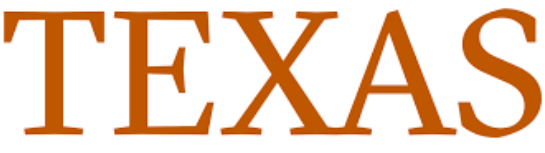

The University of Texas at Austin

PRINCETON UNIVERSITY

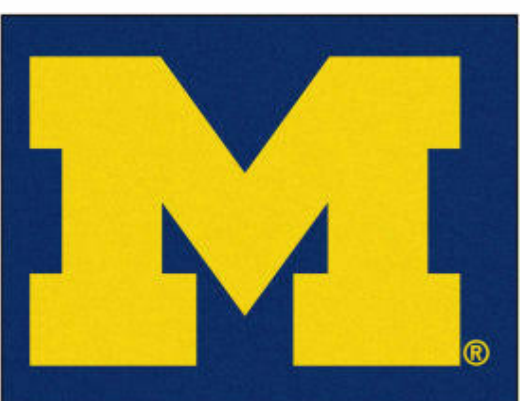

2(10[0]

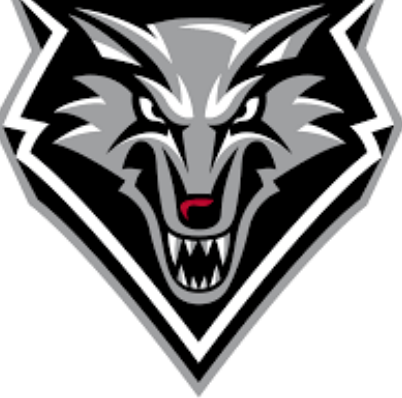

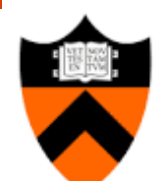

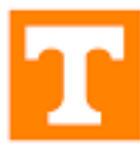

THE UNIVERSITY OF TENNESSEE KNOXVILLE

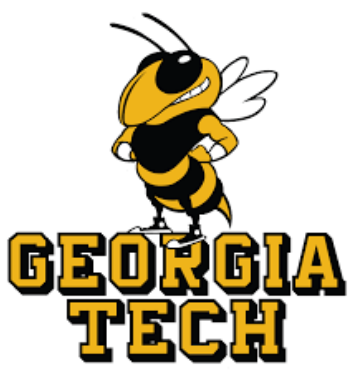

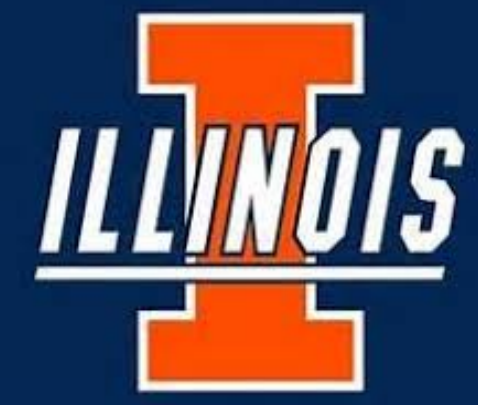

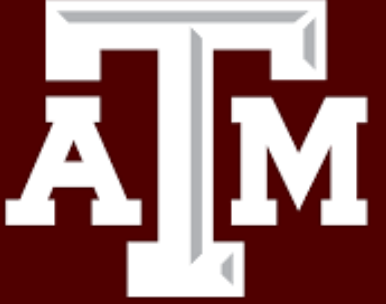

(iii) VCU

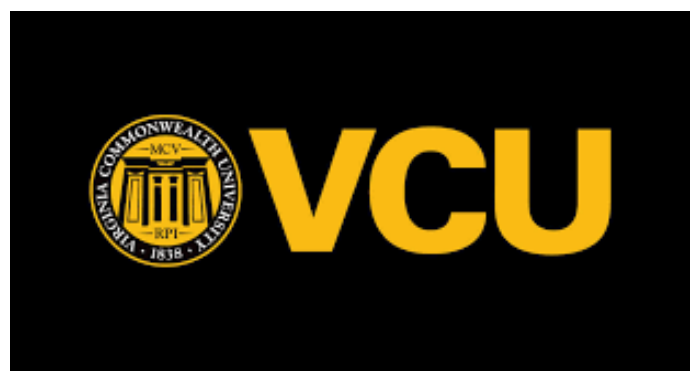

Los Alamos National Laboratory 


\section{What activities does SEE LANL typically include?}

- Basic and advanced lectures on neutron- and gammaray-based safeguards measurements (only 30 minutes each)

- Basic and advanced laboratory exercises - our focus is on hands-on laboratory experience!

- Students work with various neutron and gamma detectors used by IAEA inspectors

- Students measure special nuclear material - Pu and $U$
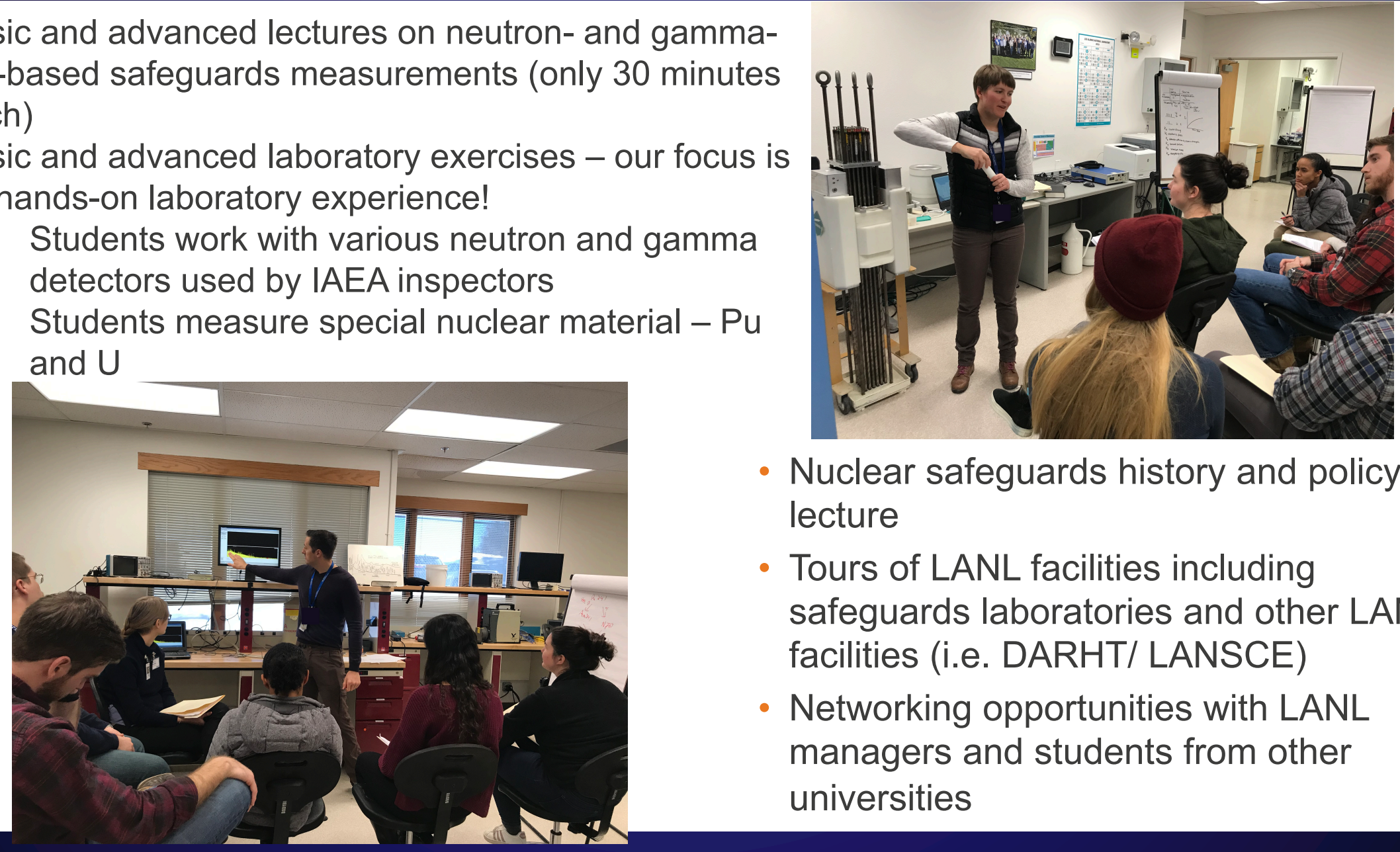

- Nuclear safeguards history and policy lecture

- Tours of LANL facilities including safeguards laboratories and other LANL facilities (i.e. DARHT/ LANSCE)

- Networking opportunities with LANL managers and students from other universities 


\section{What are student impressions of SEE LANL?}

Overall, how satisfied have you been with the training you received at SEE LANL?

7 responses

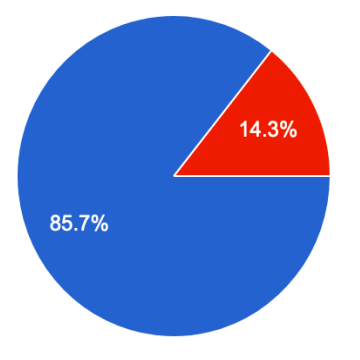

How likely are you to recommend this experience to another student?

7 responses

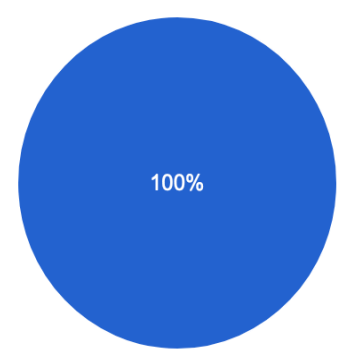

Very likely

Somewhat likely

Somewhat unlikely

Not at all likely

I would recommend this experience to another student if they were interested in a career at a national laboratory. This course is an excellent way to learn about future job opportunities, meet and network with current employees, and tour facilities.

The staff at LANL are very hospitable and helpful. Seeing special nuclear material in front of a detector in a lab environment, and to see various facilities at LANL is a very unique experience.

Valuable experience! Course material was very in-depth and began with the fundamentals. I loved that there were both introductory and advanced versions of the gamma/neutron presentations to ease the students into the material. Laboratory work was very valuable to me because I learn by doing. 


\section{Additional Resources}

\section{- Nonproliferation portal}

- https://nonproportal.energy.gov/

Resources

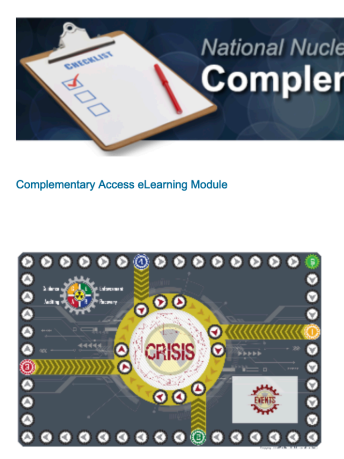

cybor Secunty for Saffouards Board Game

\section{Events and Courses}

\section{Event}

INSEP Knowledge Survey

[POSTPONED] Pacific Northwest National Laboratory Lab Day 2020

NNSA Graduate Fellowship Program (NGFP)

Introductory Course on Nuclear Nonproliferation and Safeguards (June 22nd - June 26th, 2020)

A Day in the Life of a Cyber Enabled Safeguards Inspector
Texts and Treaties

Title

Deterring Nuclear Proliferation:

Treaty on the Nonproliferation of Nuclear Weapons

New Strategic Arms Reduction Treaty (New START)

UN Security Council Resolution 1540

UN Security Council Resolution 1887

Treaty Banning Nuclear Weapon Tests in the Atmosphere, in Outer Space and Under Water

Comprehensive Test Ban Treaty

Antarctic Treaty NWFZ

Treaty for the Protibition of Nucher Weapons in Latin America and the Cribben

South Pacific Nuclear Free Zone Trealy

Treaty on the Southeast Asia Nuclear Weapon-Free Zone

African Nuclear Weapon Free Zone Treaty (Treaty of Pelindaba)

Treaty on a Nuclear-Weapon-Free Zone in Central Asia (CANWFZ)

Passive Nondestructive Assay Manual (PANDA)

Review of the Negotiation of the Model Protocol Additional to the Agreement(s) Between the State(s) and the International Atomic Energy for the Application

of Safeguards, Volume IIIII

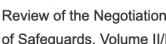

Review of the Negotiation of th

of Safeguards, Volume Illilli
External Media Type

view site Book

$\begin{array}{ll}\text { view site } & \text { Treaty } \\ \text { view PDF } & \text { Treaty }\end{array}$

$\begin{array}{lll}\text { view PDF } & \text { Treaty } \\ \text { view PDF } & \text { Treaty }\end{array}$

view PDF Treaty

view PDF Treaty

view site Treaty 